\title{
温州ミカンの果実の品質および開花に 及福す夏季の水分と窒素施用の影響
}

\author{
富田栄一 \\ （和歌山県果樹試験場）
}

\begin{abstract}
Effects of summer application of water and nitrogen on fruit
quality and flowering of Satsuma orange trees

Eiichi TомітA

Wakayama Fruit Tree Experiment Station,

Kibi-cho, Wakayama
\end{abstract}

\section{Summary}

1. Different levels of nitrogen and water were applied to Satsuma orange in summer of 1968, and their effects on fruit quality and the number of flowers in the following spring were observed. All combinations of three levels of soil moisture $(\mathrm{pF}$ $2.3,3.0,4.0)$ and two levels of nitrogen ( 0 or 18 $\mathrm{g} /$ pot) were examined.

2. As a result, the soil moisture kept at $\mathrm{pF} 3.0$ in summer was optimum for the best growth and quality of fruit. When soil moisture lowered to $\mathrm{pF}$ 4.0 , fruit weight became extremely smaller and coloring of fruits was much more retarded. On the other hand, when the soil moisture increased at $\mathrm{pF}$
2.3, soluble solids and total sugar contents in fruit juice decreased.

3. When nitrogen was applied in summer, fruit weight slightly increased, but soluble solids and total sugar contents in fruit juice were lowered and coloring of fruits was much retarded.

4. Although the number of flowers in the following spring increased with decreasing soil moisture, the growth of new shoot was checked. Even in such a case, when nitrogen was applied, the growth of new shoots was improved as well as the number of flowers.

\section{緒言}

温州ミカンの果実の生長と品質に関係する各種の栽培 要因のなかで, 土壤水分と窒素肥料の影響は大きい。果 実の生長, 品質と土壤水分の関係についてはすでに数多 くの試験成績があるが，とくに収穫前の秋季の土壤水分 が品質に強く影響することが知られている ${ }^{10,15,18,20)}$ 。窒 素の施用量および施用時期が果実の生長, 品質に执よぼ す影響についても多くの試験成績があるが，その傾向は 必らずしも一様でない。わずかに追肥を 7 月以降に施す と, 果実の着色を扰くらしたり, 浮皮の発生を助長する

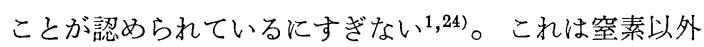
の他の要因が複雑に関与しているためと思われる14,16)。

本報告は, 温州ミカンの果実の発育期にあたる $7 〜 8$ 月の土壤水分之窒素施用の組又合せが, 果実の生長, 品 質および翌年の花数に执よぼす影響について調查したも のである。

\section{材料および方法}

1967年 4 月に, 径 $60 \mathrm{~cm}$, 深さ $45 \mathrm{~cm}$ のコンクリート 1971 年 3 月 15 日受理
ポット（有底）に埴土を入れ，同時にポットあたりコン ポスト $2 \mathrm{~kg}$, 苦土石灰 $1 \mathrm{~kg}$ を全層に施用して, 2 年生 林系温州ミカンを植付けた。以後 1968 年 6 月までは, いずれの樹も同一に管理して, 同年 7 月から処理を開始 した。

処理区は, 土壤水分を $\mathrm{pF} 2.3,3.0,4.0$ の 3 段階に, 窒素施用を無施用, 施用の 2 段階として, これらを組み 合せた 6 処理区で， 1 区 4 本を供試して，7月 11 日から 9 月 10 日までの 2 か月間処理を行なつた。

土壤水分の処理方法は, 洋ット内の深さ $15 \mathrm{~cm}$ の土壤 水分が所定の $\mathrm{pF}$ 值にまで低下したとき，ポットあたり $10 l$ のかん水を行なつて, 土壤水分を固場容水量以上に した。処理期間中はこれを繰返した。窒素施用区はポ ットあたり窒素成分で $18 \mathrm{~g}$ を 7 月 9 日よび 8 月 10 日 の 2 回, 硫安で施用した。な和, 他の肥料は施用しなか つた。各区とも処理終了後（9月11日以降）は十分にか ん水を行ない，また施肥は行なわず，翌年の 7 月まで同 一に管理した。

土壤水分の测定は, ポット内の深さ $15 \mathrm{~cm}$ の位置に, 
テンシオメーター叔よびガラスブロック型土垬水分計を 埋設して行なつた。な誩，処理開始時までに施用した施 肥量は，ポットむたり 1967 年に年間 N， P ，K をそれぞ れ 20-10-15g の割合で 4 回に分施し，1968 年は 12-6$8 \mathrm{~g}$ で 3 月拉よび 4 月の 2 回に分けて施用した。施用し た肥料は硫安，ヨウリン，硫加である。

供試樹は 7 月上旬に摘果を行なつて，25 葉に 1 果の割 合となるよう結实させ，12月 5 日に果実を収穫して果䒠 の品質を調查した。また，果皮の着色度をみるために， 11月 5 日に果皮のクロロフィル含量を定量した。この場 合, 果汁の可溶性固形物含量は検糖計で, 糖含量はSoMOGYI 法で, 酸含量は中和滴定法でクエン酸として求 め, 果皮のクロロフィル含量は色素を $80 \%$ ソセトンで 抽出したのち, 分光光度計で $665 \mathrm{~m} \mu$ に护ける吸光度を 測定して求めた。翌年の 1969 年 5 月から 6 月にかけて, 開花期，開花数执よび新梢伸長量を調査した。

春葉の窒素拈よび炭水化物含量は, 不結果枝の春葉を 9 月 10 日拉よび 12 月 6 日の 2 回採葉して分析した。分 析方法は, 窒素は semi-micro KJELDAHL 法, 炭水化 物はSOMOGYI 法で行なつた。

供試土壤の機械分析拉よび水分恒数は第 1 表に示すと 扣りである。機械分析はピペット法，水分恒数はテンシ オメーター法狺よび遠心分離法で求めた。

\section{実 験 結 果}

果実の生長, 品質 果实の生長, 品質は第 2 表に示

第 1 表 供試土壤の機械分析括よび水分恒数

\begin{tabular}{|c|c|c|c|c|c|c|c|}
\hline \multicolumn{4}{|c|}{ 機械分析 $(\%)$} & \multicolumn{4}{|c|}{ 水分恒数 (容量 \%) } \\
\hline 粗砂 & 細砂 & 微砂 & 粘土 & pF 2. & $\mathrm{pF} 2.3 \mathrm{pF} 3.0$ & $\mathrm{pF} 4.0$ & $\mathrm{pF} 4.2$ \\
\hline 16.6 & 28.4 & 26.5 & 28.5 & 8.4 & $48.9 \mid 34.0$ & 23.7 & 20.1 \\
\hline
\end{tabular}

第 2 表 温州ミカンの果実の品質に及ぼす夏季の土㖶水分と 窒素施用の影響（12月 5 日）

\begin{tabular}{|c|c|c|c|c|c|c|c|c|c|}
\hline 処 & 区 & $\begin{array}{c}\text { 二果 } \\
\text { 平均 } \\
\text { 重 } \\
(\mathrm{g})\end{array}$ & $\begin{array}{l}\text { 果皮 } \\
\text { 歩合 } \\
(\%)\end{array}$ & \begin{tabular}{|}
$\left|\begin{array}{c}\text { 可溶性 } \\
\text { 固形物 } \\
(\%)\end{array}\right|$ \\
$(\%)$
\end{tabular} & $\begin{array}{l}\text { 還元 } \\
\text { 糖 } \\
(\%)\end{array}$ & $\begin{array}{l}\text { 全糖 } \\
(\%)\end{array}$ & $\begin{array}{c}\text { クェン } \\
\text { 酸 } \\
(\%)\end{array}$ & $\begin{array}{l}\text { 甘 } \\
\text { 味 } \\
\text { 率 }\end{array}$ & $\begin{array}{l}\text { 果汁中の } \\
\text { 窒素含量 } \\
\left(\begin{array}{c}\mathrm{mg} / \\
100 \mathrm{ml}\end{array}\right)\end{array}$ \\
\hline \multicolumn{2}{|c|}{$-\mathrm{N} \mathrm{pF} 2.3$} & 101 & 27.7 & 10.5 & 3. 42 & 7.23 & 1.68 & 4.30 & 36 \\
\hline \multicolumn{2}{|r|}{3.0} & 101 & 27.7 & 11.1 & 3.63 & 7.95 & 1.67 & 4.76 & 35 \\
\hline \multirow{2}{*}{\multicolumn{2}{|c|}{$\begin{array}{r}4.0 \\
+\mathrm{N} F ? 3\end{array}$}} & 82 & 28.9 & 12.8 & 4.18 & 8.91 & 1.54 & 5.79 & 47 \\
\hline & & 103 & 29.8 & 9.4 & 3.41 & 6.14 & 1.51 & 4.07 & 52 \\
\hline & $+\mathrm{N} p \mathrm{pr} 2.3$ & 105 & 29.7 & 10.3 & 3.23 & 6.73 & 1.67 & 4.03 & 53 \\
\hline \multicolumn{2}{|r|}{4.0} & 92 & 32.8 & 11.5 & 3.63 & 8.24 & 1.57 & 5.25 & 79 \\
\hline $\begin{array}{l}\text { 有 } \\
\text { 意 } \\
\text { 性 }\end{array}$ & $\begin{array}{l}\text { 土鎄水分 } \\
\text { 窒素施用 }\end{array}$ & $\begin{array}{l}* * \\
*\end{array}$ & $\begin{array}{c}* \\
* *\end{array}$ & $\begin{array}{l}* * \\
* *\end{array}$ & * & $\begin{array}{l}* * \\
* *\end{array}$ & $\begin{array}{l}\text { N.S. } \\
\text { N.S. }\end{array}$ & $\begin{array}{c}* * \\
*\end{array}$ & $\begin{array}{l}* * \\
* *\end{array}$ \\
\hline
\end{tabular}

注） N.S. : $5 \%$ 水準の F 值で有意性のないことを示す。

* : $5 \%$ 水準の $\mathrm{F}$ 值で有意性のあることを示す。

**: $1 \%$ 水準の $\mathrm{F}$ 值で有意性のあることを示す。

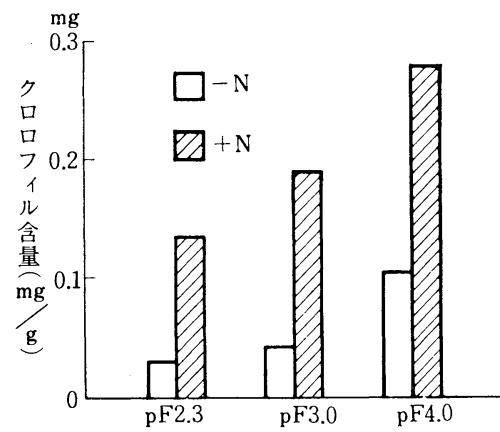

第 1 図 温州ミカン果皮のクロロフィル含量に 及ぼす夏季の土壤水分と窒素施用の影響 (11月 5 日)

すと扣りである。1 果平均重は窒素施用の有無にかかわ らず, pF 4.0 区で最も劣り, その傾向は窒素の無施用の 場合にはなはだしく，反詨に窒素施用の $\mathrm{pF} 3.0$ 区で最 もすぐれた。

果汁の可溶性固形物および全糖含量は土壤水分が低下 するにつれて高くなり，甘味率は $\mathrm{pF} 4.0$ 区で最も高く， クエン酸含量は土壤水分の多少による差がなかつた。窒 素を施すと，果汁の窒素含量は高くなるが，果汁の可溶 性固形物，全糖含量执よび甘味率は低下した。この場 合, クエン酸含量には差がなかつた。

収穫 1 か月前から収穫洔までの果汁の可溶性固形物含 量の変化をみると，第 3 表のとおりで，各区とも収穫期 に近ずくにつれて，可溶性固形物含量は増加した が，この傾向は窒素が無施用で土壤水分が少ないは ぞ著しかつた。結局, 可溶性固形物含量よりみて, 空素施用区では無施用区にくらべて, 約 $2 \sim 3$ 週間 成熟が遅れた。

つぎに, 11 月 5 日の果皮のクロロフィル含量は第 1 図に示すと物りである。すなわち，土壤 水分が低下するにつれてクロロフィル含量 は多くなり, 窒素を施すとさらに増加し

第 3 表 温州ミカンの果汁の可溶性固 形物含量の変化に及注す夏季の土 壤水分と窒素施用の影響

\begin{tabular}{r|r|r|r}
\hline \multicolumn{1}{c|}{ 処 理 区 } & $\begin{array}{c}11 \text { 月 5 日 } \\
(\%)\end{array}$ & $\begin{array}{r}11 \text { 月20日 } \\
(\%)\end{array}$ & $\begin{array}{r}12 \text { 月 5 } \\
(\%)\end{array}$ \\
\hline$-\mathrm{N} \mathrm{pF} \mathrm{2.3}$ & 9.2 & 10.0 & 10.5 \\
3.0 & 9.2 & 10.4 & 11.1 \\
4.0 & 10.2 & 11.5 & 12.8 \\
$+\mathrm{N} \mathrm{pF} \mathrm{2.3}$ & 8.0 & 8.8 & 9.4 \\
3.0 & 8.4 & 9.0 & 10.3 \\
4.0 & 9.8 & 10.2 & 11.5 \\
\hline
\end{tabular}


た。したがつて, 果皮の緑色の消失は, 窒素施用の $\mathrm{pF}$ 4.0 区で最も遅れ, 窒素無施用の $\mathrm{pF} 2.3$ 区拉よび 3.0 区 で最も早かつた。結局, 収穫時 (12 月 5 日) には, 窒素 無施用の pF 2.3 区拉よび 3.0 区では果皮の橙色が濃く， かつ肌が滑らかで外観の美しい果実であり，他方，窒素 施用の各区では橙色より黄色の色調が強く，果皮は粗で あり，外観は劣つた。

翌年の開花および新梢伸長 各処䞏区の翌年の 開花期, 開花数㧊よび新梢伸長量は第 4 表のと特りであ る。開花期は土壌水分の少ない区汪ど早く，この傾向は 窒素の施用でより助長され, 窒素施用の $\mathrm{pF} 4.0$ の区で 最も早かつた。翌年の 1 樹あたりの開花数は, 土壤水分 の少ない区ほど多く，かつ，いずれの土壤水分レベルで も窒素を施すと增加した。反対に, 翌年の 1 樹あたりの 新梢伸長量扣よび新葉数は, 土壤水分の少ない区ほど劣 り，それらはいずれの土壤水分レベルでも窒素を施すと 増大した。

春葉の体内成分 処㻎終了時 (9 月10日) の春葉 の体内成分は第 5 表に示すと扣りである。水溶性窒素は 土㙵水分が低下するにつれて高くなり，その值はいずれ の土壤水分レベルに扣いても窒素の施用により堌大した。 不溶性窒素は窒素施用区で土壤水分が低下するにつれて

第 4 表 翌年の温州ミカンの開花期，開花数掞よび 新梢伸長量に及ぼす夏季の土榱水分と窒素施用 の影響

\begin{tabular}{|c|c|c|c|c|c|c|}
\hline \multicolumn{2}{|c|}{ 処 理 区 } & $\begin{array}{l}\text { 開花期 } \\
\text { (月日) }\end{array}$ & $\begin{array}{l}\text { 開花 } \\
\text { 数 }\end{array}$ & $\begin{array}{l}\text { 新 梢 } \\
\text { 伸長量 } \\
\text { (cm) }\end{array}$ & $\begin{array}{c}\text { 新葉 } \\
\text { 数 }\end{array}$ & $\begin{array}{l}\text { 新葉 } \\
\text { 総面積 } \\
\left(\mathrm{cm}^{2}\right)\end{array}$ \\
\hline \multicolumn{2}{|c|}{$-\mathrm{N} \mathrm{pF} 2.3$} & 5.14 & 169 & 404 & 250 & 3,300 \\
\hline \multicolumn{2}{|c|}{3.0} & 12 & 326 & 368 & 242 & 3,000 \\
\hline \multicolumn{2}{|c|}{4.0} & 12 & 603 & 204 & 175 & 3,500 \\
\hline \multicolumn{2}{|c|}{$+\mathrm{N} \mathrm{pF} 2.3$} & 11 & 497 & 749 & 503 & 17,900 \\
\hline \multirow{2}{*}{\multicolumn{2}{|c|}{$\begin{array}{l}3.0 \\
4.0\end{array}$}} & 11 & 483 & 742 & 480 & 15,800 \\
\hline & & 9 & 902 & 365 & 326 & 14,100 \\
\hline $\begin{array}{l}\text { 有 } \\
\text { 意 } \\
\text { 性 }\end{array}$ & $\begin{array}{l}\text { 土壤水分 } \\
\text { 窒素施用 }\end{array}$ & - & $\begin{array}{l}* * \\
* *\end{array}$ & $\begin{array}{l}* * \\
* *\end{array}$ & $\begin{array}{l}* * \\
* *\end{array}$ & $\begin{array}{l}\text { N.S. } \\
* *\end{array}$ \\
\hline
\end{tabular}

第 5 表 温州ミカン春葉内成分 (9月 10 日) に及ぽ 寸夏季の土壤水分と窒素施用の影響(乾物\%)

\begin{tabular}{|c|c|c|c|c|c|c|c|c|}
\hline \multicolumn{2}{|c|}{ 処 理 区 } & $\begin{array}{l}\text { 水溶 } \\
\text { 性 } \\
\text { 窒素 }\end{array}$ & $\begin{array}{l}\text { 不溶 } \\
\text { 性 } \\
\text { 窒素 }\end{array}$ & $\begin{array}{l}\text { 全 } \\
\text { 窒素 }\end{array}$ & $\begin{array}{c}\text { 還元 } \\
\text { 糖 }\end{array}$ & $\begin{array}{l}\text { 韭還 } \\
\text { 元糖 }\end{array}$ & 全 & $\begin{array}{l}\text { 全炭 } \\
\text { 水化 } \\
\text { 物 } \\
\end{array}$ \\
\hline \multicolumn{2}{|c|}{$-\mathrm{N}$ pF 2.3} & 0.44 & 1.99 & 2.43 & 2.32 & 3.84 & 6.16 & 18.93 \\
\hline \multicolumn{2}{|c|}{3.0} & 0.50 & 1.96 & 2.46 & 2.32 & 3. 41 & 3 & 16.14 \\
\hline & 0.73 & 2.26 & 2.99 & 2.55 & 2.82 & 5.37 & 12.91 \\
\hline \multicolumn{2}{|c|}{$+\mathrm{N}$ pF 2.3} & 0.69 & 3.01 & 3.70 & 2.15 & 3.18 & 5.33 & 15.43 \\
\hline \multirow{2}{*}{\multicolumn{2}{|c|}{4.0}} & 0.81 & 2.74 & 3.55 & 2.14 & 2.94 & 5.08 & $15 \cdot 10$ \\
\hline & & 1.15 & 2.55 & 3.70 & 2.26 & 1.66 & 3.92 & 12.06 \\
\hline $\begin{array}{l}\text { 有 } \\
\text { 意 } \\
\text { 性 }\end{array}$ & $\begin{array}{l}\text { 土裹水分 } \\
\text { 窒素施用 }\end{array}$ & \begin{tabular}{ll|}
$*$ & $*$ \\
$*$ & $*$
\end{tabular} & $\begin{array}{l}\text { N.S. } \\
* *\end{array}$ & $\begin{array}{l}* * \\
* *\end{array}$ & $\begin{array}{c}\text { N.S. } \\
*\end{array}$ & $* *$ & $\begin{array}{l}* * \\
* *\end{array}$ & $*$ \\
\hline
\end{tabular}

第 6 表 温州ミカン春葉内成分 (12月 6 日) に及ぼ 寸夏季の土壤水分と窒素施用の影響(乾物\%)

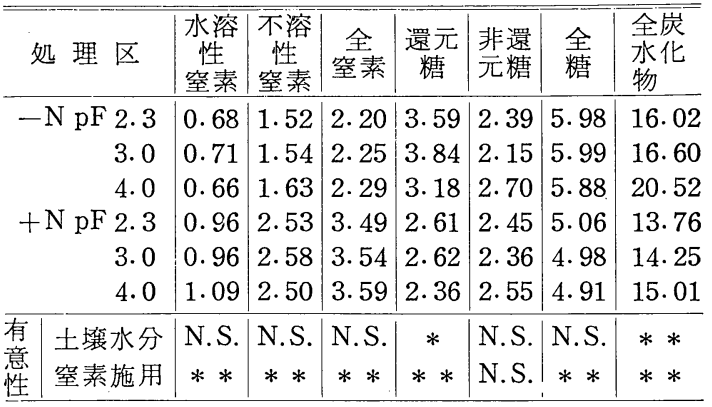

低くなり，全窒素は窒素無施用区で $\mathrm{pF} 4.0$ 区が高く， また，それらはいずれの土壤水分レベルに拈いても窒素 の施用によりその值は増大した。反対に, 非還元糖, 全 糖括よび全炭水化物は, 土壌水分が低下寸るにつれて低 くなり，窒素の施用によりその值はさらに低下した。

収穫時（12月 6 日）の春葉の体内成分は第 6 表のと特 りで, 水溶性, 不溶性扣よび全窒素は土壤水分の多少に よる差はなかつたが，窒素施用区は無施用区にくらべて 著しく高かつた。

\section{考察}

本突験は, 温州ミカンの果実の発育期にあたる $7 〜 8$ 月に捇ける土壤水分ならびに窒素施用が温州ミカンの果 突の生長, 品質および翌年の開花に执よぼす影響をみた ものである。ただし, 土壤水分については水分当量 $(\mathrm{pF}$ 3.0）を中心にして, pF 2.3 区特よび $\mathrm{pF} 4.0$ 区を設け た。

その結果, 1 果平均重では窒素の施用の有無にかかわ らず，水分当量 (pF 3.0) 付近ですぐれ, pF 4.0 になる と著しく劣つた。果皮の着色は水分当量以上，すなわち pF 2.3 区执よび pF 3.0 区ですぐれた。しかし，窒素を 施すと, 着色ははなはだ劣つた。この点については,す でに夏季の土銥乾燥が温州ミカンの果皮の着色の不良を 招くこと ${ }^{10,18,20,22)}$ ，扣よび窒素施用量が多いと着色の遅 れること ${ }^{14,17,21,22,24)}$ が報告されている。

果汁中の可溶性固形物扎よび全糖含量は, 土壤水分が 低下するにつれて高くなつた。このことについては，こ れまでの成績によると, 夏季の土壤乾燥によつて高くな る場合 ${ }^{10,20,22)}$ と， ほとんど差がない場合 ${ }^{18)}$ があり，土壤 乾燥の影響としては夏季より秋季の方が顕著である場合 が多い。つぎに，窒素の影響についてみると，果汁中の 可溶性固形物含量あるいは糖含量が，窒素施用量が少な いほど高くなる場合 ${ }^{2,9,14,22) ， と く に 8 〜 9 月 あ る い は 10 ~}$ 〜11月に窒素の供給を欠除すると高くなる場合4,5) が報 告されているが，本実験の結果は後者と一致した。しか 
しながら，反対に果汁中の可溶性固形物含量が，窒素施 用量が多くなるにつれて高くなる場合 ${ }^{11,16)}$ と， ほとんど 差がない場合 ${ }^{1,3)}$ の成績もある。他の柑橘についても同じ ような結果の報告 $6,7,8,12,13)$ がある。このように，果汁中 の可溶性固形物含量に拉よぼす窒素の影響が一様でない のは，樹体条件や土壤条件などの違いによつて，窒素以 外の他の要因が複雑に関与してくるためと思われる。本 実験の場合，夏季に窒素を施すと，果汁中の可溶性固形 物含量が明らかに低下したが，これは 9 月以降の窒素無 施用区と施用区の春葉の全窒素含量の違いが大きく，12 月 6 日では窒素無施用区の $2.2 \sim 2.3 \%$ に対し, 窒素施 用区では 3.5〜3.6\% であり，著しく高かつたためと思 われる。

な括，温州ミカンの果実の生育時期と関連して，果汁 中の可溶性固形物含量に扣よぼす窒素の影響は, 本実験 のごとく夏季の場合には，土壤水分の乾湿に関係なく認 められるが, 秋季の場合には, 土壤水分が乾燥状態のと きにはその影響が認められない21,23)。このよ5に，果実 の生育時期拉よび土壤水分の乾湿の違いによつて, 果汁 中の可溶性固形物含量に特よぽす窒素の影響が異なるこ とは與味深い。

果汁中のクエン酸含量については, 処理による影響が なかつたが，土壤水分の影響については処理終了後各区 とも十分にかん水を行なつたためと思われ20), 窒素の影 響については窒素施用量が多くなると高くなること ${ }^{14,16)}$ が報告されているが，本実験の場合，窒素処理による影 響の差がなかつたことについては，その理由が明らかで ない。

翌年の開花扣よび新梢伸長におよぼす処理の影響をみ ると, 土壤水分の少なかつた区ほど開花数が多く，とく に pF 4.0 区ではなはだ多かつたが，新梢伸長量および 新葉数は劣つた。この場合, 窒素施用区では無施用区に くらべて, 開花数, 新梢伸長量および新葉数はともに,

第 7 表 温州ミカンの開花数と前 年の春葉内成分との間の相関 関係

\begin{tabular}{l|c|c}
\hline 葉内成分 & 9 月 10 日 & 12 月 6 日 \\
\hline 水溶性窒素 & $0.878^{* *}$ & $0.582^{* *}$ \\
不溶性窒素 & 0.350 & $0.417^{*}$ \\
全 窒 素 & $0.598^{* *}$ & $0.478^{*}$ \\
還 元 糖 & 0.146 & $-0.511^{*}$ \\
非 還 元 糖 & $-0.740^{* *}$ & 0.356 \\
全 糖 & $-0.726^{* *}$ & -0.368 \\
全炭水化物 & $-0.649^{* *}$ & 0.052 \\
\hline
\end{tabular}

注） *: $5 \%$ 水準で有意な相関めり。 **: $1 \%$ 水準で有意な相関あり。
いずれの土壤水 分レベルに拉い ても增大した。 一般に, 土壤乾 燥が温州ミカン の翌年の開花数 を多くすること は経験的に知ら れているが，こ の点について, 鉿木ら ${ }^{18)}$ は温州 ミカンの時期別
土壤乾燥処理が装年の結䒠におよぼす試験のなかで, 7 〜8 月に断水処理した樹はかん水した樹にくらべて, 翌 年の開花数の多くなることを認め，樹体の栄養生長が一 時的に停止する程度に土壤がひどく乾燥すると, 冬季の 花芽分化を促がし, その結果, 翌年の花蕾着生を有利に 導いたのではないかと報告している。

つぎに，開花数は第 7 表で明らかなように，前年の 9 月および 12 月の春葉の窒素含量と有意な正の相関関係 にあり，本実験の場合，春葉の全窒素含量が， 9 月から 12 月にかけて窒素無施用区では 3.0 2.2\% の範囲であ つたのにくらべ，窒素施用区では 3.7〜3.5\% であり， 秋季に和ける樹体の同化養分の集積は窒素施用区で多 く，このことが翌年の開花数を多くしたのではないかと 考えられる。

翌年の新梢伸長量および新葉数は, 土壤水分の少なか つた区ほど劣り，pF 4.0 区で最も少なかつたが，これ は $\mathrm{pF} 4.0$ 区では開花数が多かつたため, 反対に栄養生 長が抑制されたものと思われる。なお，新梢伸長量およ び新葉数は, 窒素施用区にくらべて無施用区で著しく劣 つたが，冬から翌春にかけての窒素無施用区の体内の窒 素レベルが低かつたので, 栄養生長にとつて低窒素レベ ルが制限要素になつたものと思われる。

\section{摘 要}

1. コンクリートポットに植えた 3 年生林系温州ミカ ンについて， 7 月 11 日から 9 月 10 日までの 2 カ月間, 土壌水分を $\mathrm{pF} 2.3,3.0,4.0$ に調整し, この各々に窒 素の無施用区と施用区を設け，果実の生長，品質および 翌年の開花に执よぼす影響をみた。

2. その結果，夏期（7～8 月）飞土壤水分を水分当量 （pF3.0）付近に保つことは，果字の生長，品質の点より みて，もつとも好適であつた。土壤水分がこれよりも少 なく, pF4.0になると，果重が著しく劣るとともに果皮 歩合が大となり，かつ着色がはなはだしく覀くなつた。 反対に土壤水分がこれより多く $\mathrm{pF} 2.3$ になると，果汁 中の可溶性固形物特よび全糖含量が低下した。

3. 夏期に窒素を施すと，果重はやや増大するが，果 皮歩合が高くなるとともに，果汁中の可溶性固形物扣よ び全糖含量が低下し，果皮の着色が著しく劣つた。

4. 夏期に土壤水分が少ない注と，翌年の開花数は増 加し, 反対に新梢伸長量は衰えた。この場合，夏期に窒 素を施すと, 開花数, 新梢伸長量はともに増大した。

謝辞 この報告をするにあたつて，ご校閲と教示を賜 わつた京大農学部教授小林 章博士，実験の遂行にあた つて，ご指導と便宜をいただいた前和歌山果試場長東 史郎氏に梁く感謝の意を表する。

また，費用の一部は農林省総合助成試験費によつた。 


\section{引用文献}

1. 赤松 聡 - 大和田厚 - 船上和喜. 1970. 昭和45年 度春季園芸学会研究発表要旨. pp. 48-49.

2. 莘沢正義. 1969. 果実日本. $24(5)$ ：56-59.

3. 平方康夫 - 岩本数人・宮崎久哉・大津量男. 1965 . 熊本果試業務報告. pp. 142-146.

4. 井上 宏. 1968. 昭和 43 年度秋季園芸学会研究 発表要旨. pp. 102-103.

5. 岩本数人 - 宮崎久哉 - 大津量男 - 金川英明. 1967. 熊本果試業務報告. pp. 256-261.

6. Jones, W. W., and E. R. PARKER. 1949. Proc. Amer. Soc. Hort. Sci. $53: 91-102$.

7. and T. W. EMBLETON. 1967. Proc. Amer. Soc. Hort. Sci. 91 : 138-142.

8. —— and R.G. Plat T. 1968. California Citrograph. 53(10) : 367.

9. 小園照雄 - 松尾 平. 河瀬憲次. 1966. 昭和41年 度秋季園芸学会研究発表要旨. pp. 33-34.

10. 栗山隆明 - 白石真一. 1967. 昭和 42 年度春季園芸 学会研究発表要旨. pp. 132-133.

11. 中原美智男 - 山本正人 - 岩切徹. 1967. 昭和 42 年度秋季園芸学会研究発表要旨. pp. 112-113.

12. Reuther, W., and P.F.Smith. 1952. Proc. Amer. Soc. Hort. Sci. $59: 1-12$.
13. G. HRNCIAR. 1957. Proc. Amer. Soc. Hort. Sci. $70: 223-236$.

14. 坂本辰馬. 奥地 進. 1968. 園学雑. 37 (1) : 30 -36 .

15. — 1 - 1968. 園学雑. $37(3): 212$ -220 .

16. 一 1 1969. 園学雑. 38(4) : 300 $-308$.

17. 佐藤公一 - 石原正義 - 栗原昭夫. 1958. 農技研報. $\mathrm{E}(7): 17-39$.

18. 鈴木鉄男・金子 衛・田中 実. 1967. 園学雑. 36(4) : 389-398.

19. 一一. 1969. 園学雑. $38(4): 287-294$.

20. 富田栄一 - 東 串郎. 1969. 和歌山果試研究報告. 2 : 33-59.

21. 一 - 1969. 昭和 44 年度春季園 芸学会研究発表要旨. pp. 100-101.

22. 一一 1969. 農及園. $44(11) ： 1727-1728$.

23. - - 1970. 昭和 45 年度秋季園 芸学会研究発表要旨. pp. 100-101.

24. 鳥潟博高・増井正夫・鈴木 登. 1955. 園芸学研 究集録. $7: 42-48$. 